\title{
Pengaruh motivasi mu'amalat (bekerja dan berproduksi, kebutuhan sekunder, kebutuhan primer) terhadap prestasi kerja yang religius
}

\author{
Chablullah Wibisono, \\ Fakultas Ekonomi Universitas Batam \\ E-mail: chablullahwibisono@yahoo.co.id
}

\begin{abstract}
Observing the development and growth of modern markets that is not comparable to traditional markets and folk market, has described the tendency of secondary needs (psychological) which are dominant, and has been proven by Consumption Patterns Survey Central Bureau of Statistics (19912012). The survey shows that spending to meet the secondary needs amounted to $62.56 \%$ while for the primary requirement of $37.44 \%$. The order to meet the secondary needs and primary needs exist in the Qur'an, but all of them in order to improve the achievement of the religious (pious charity) is not to satisfaction solely. Based on a survey of consumption patterns and theories about the need for secondary and work performance, attractive to the research, is there a need for Secondary Effect on Achievement of the Religious? From the loading factor corfirmatory mu'amallat with second order factor Analysis is as follows: secondary needs loading factor $=1.00$ (significant). This figure shows that the needs of most large secondary needs described by the variation of mu'amallat motivation. In other words secondary requirement is the most powerful indicator (dominant) of mu'amallat motivation (work and production, needs secondary, needs primary, work performance of religious).
\end{abstract}

Mengamati perkembangan dan pertumbuhan pasar modern yang tidak dapat dibandingkan dengan pasar tradisional dan pasar rakyat mengambarkan kecenderungan kebutuhan sekunder (psikologis) yang dominan, dan telah dibuktikan dengan Survey Pola Konsmsi yang dilakukan oleh Biro Pusat Statistik (1991-2012). Survey ini menunjukkan bahwa belanja untuk kebutuhan sekunder mencapai $62,56 \%$ sementara untuk kebutuhan primer mencapai 37,44\%. Perintah untuk memenuhi kebutuhan sekunder dan kebutuhan primer terdapat dalam al-Qur'an, namun semua itu untuk memperbaiki capaian keagamaan (sedekah) bukan semata untuk kepuasan. Berdasarkan survey pola konsumsi dan teori mengenai kebutuhan sekunder dan performa kerja, penelitian ini mempersoalkan apakah kebutuhan sekunder itu ada pengaruhnya atas pencapaian keagamaan? Dari penelitian ini diketahui bahwa loading 
ljtihad, Jurnal Wacana Hukum Islam dan Kemanusiaan, Volume 13, No. 2, Desember 2013: 233-252

factor dari kebutuhan sekunder adalah 1.00 (signifikan). Gambaran ini memperlihatkan bahwa pemenuhan kebutuhan sekunder paling banyak dikendalikan oleh berbagai motivasi mu'amalat. Dengan kata lain, kebutuhan sekunder merupakan indikator paling dominan dari motivasi mu'amalat, yakni kerja dan produksi, kebutuhan sekunder, kebutuhan primer, dan performa kerja religious.

Keywords: Work and production; Secondary needs; Primary needs; Religious work performance

\section{Pendahuluan}

Pola kebutuhan dalam motivasi mu'amallat dengan variabel indikator bekerja dan berproduksi, kebutuhan sekunder, kebutuhan primer, bila dibandingkan dengan pola kebutuhan menurut Maslow yang berparadigma sekuler, terdapat pola yang sama secara fitrah manusia, namun ada perbedaan pada cara pendekatan dan motifnya. Perbedaan antara ilmu ekonomi modern dengan ekonomi Islam dalam pola konsumsi terletak pada cara pendekatannya dalam memenuhi kebutuhan seseorang. Islam tidak mengakui kegemaran materialistis semata-mata dari pola konsumsi modern, tetapi Islam mengajarkan keseimbangan antara material dan spritual.

Mencermati perkembangan dan pertumbuhan pasar modern yang tidak sebanding dengan pasar tradisional dan pasar rakyat, telah menggambarkan adanya kecenderungan kebutuhan sekunder (psikologi) secara dominan, dan telah dibuktikan dengan Survei Pola Konsumsi Badan Pusat Statistik (1991-2012). Survei itu menunjukkan pengeluaran untuk memenuhi kebutuhan sekunder tahun sebesar $62,56 \%$ sedangkan untuk kebutuhan primer sebesar $37,44 \%$. Perintah untuk memenuhi kebutuhan sekunder maupun kebutuhan primer ada dalam al-Qur'an, tetapi semuanya itu dalam rangka untuk meningkatkan prestasi kerja yang religius (amal shaleh) bukan untuk kepuasan semata-mata. Pemenuhan kebutuhan sekunder dibenarkan oleh Islam akan tetapi ditujukan untuk meningkatkan prestasi kerja dan tidak boleh mengabaikan kebutuhan primer (pokok). Rasulullah menyimpulkan bahwa kebutuhankebutuhan pokok bagi setiap anggota masyarakat harus tersedia (Rahman,1995: 40-41). Kebutuhan pokok seperti makanan, pakaian dan tempat tinggal, yang perlu bagi peningkatan efisiensi kerja disebut "kebutuhan tepat guna" untuk meninkatkan prestasi kerja yang religius.

Memenuhi kebutuhan sekunder untuk meningkatkan prestasi kerja, dalam koridor keIslaman dapat diartikan bahwa menikmati suatu kesenangan diperbolehkan dalam Islam. 
Islam sangat memahami naluri alamiah manusia dalam mengagumi dan menikmati keindahankeindahan dalam hidup ini. Islam juga mengakui kebutuhan-kebutuhan budaya manusia. Dalam masalah kebutuhan-kebutuhan manusia akan keindahan dan budaya secara alamiah, Islam membolehkannya mengikuti kebutuhan-kebutuhan pokok manusia, menikmati kesenangan-kesenangan. Pemenuhan kebutuhan sekunder dibenarkan oleh Islam, dalam alQur'an Surat al- A'raf ayat 31 menganjurkan kepada kaum muslimin untuk menikmati halhal yang baik dan indah. Jadi jelaslah bahwa pemuasan keinginan, termasuk kenyamanankenyamanan, keindahan dan perhiasan-perhiasan hidup dibolehkan dan dihalalkan asalkan untuk meningkatkan prestasi kerja, karena merupakan keinginan yang memberikan kesenangan dan kenyamanan kepada manusia dan yang memiliki manfaat (utility) yang lebih besar dari harganya (Rahman, 1995: 42).

Berdasarkan survei pola konsumsi dan teori-teori mengenai kebutuhan sekunder dan prestasi kerja, menarik untuk diadakan penelitian, apakah ada Pengaruh Kebutuhan Sekunder terhadap Prestasi kerja yang religius? Dari hasil loading factor mu'amallat dengan second order corfirmatory factor analisys adalah sebagai berikut: kebutuhan sekunder loading factor $=1,00$ (signifikan). Angka tersebut menunjukkan bahwa kebutuhan kebutuhan sekunder yang paling besar dijelaskan oleh variasi dari motivasi mu'amallat. Dengan kata lain kebutuhan sekunder merupakan indikator yang paling kuat (dominan) dari motivasi mu'amallat. Semoga hasil penelitian ini bermanfaat untuk perkembangan Manajemen Sumberdaya Manusia terutama pada variabel-variabel motivasi yang dapat mempengaruhi secara signifikan terhadap prestasi kerja yang religius.

Berdasarkan permasalahan yang muncul ditengah kehidupan umat Islam yang merupakan bagian dari kehidupan ekonomi, sebaigaimana uraian pada pendahuluan tersebut diatas dapat disimpulkan dalam rumusan masalah sebagai berikut: Apakah bekerja dan berproduksi berpengaruh terhadap prestasi kerja yang religius?; Kebutuhan sekunder berpengaruh terhadap prestasi kerja yang religius?; Apakah kebutuhan primer berpengaruh terhadap prestasi kerja yang religius?; Manakah di antara bekerja dan berproduksi, kebutuhan sekunder, kebutuhan primer, yang paling dominan berpengaruh terhadap prestasi kerja yang religius?

Penelitian ini bertujuan untuk menganalisis dan menguji: apakah bekerja dan berproduksi, kebutuhan sekunder dan kebuyuhan primer berpengaruh terhadap prestasi kerja yang religius 
ljtihad, Jurnal Wacana Hukum Islam dan Kemanusiaan, Volume 13, No. 2, Desember 2013: 233-252

pada karyawan perusahaan manufaktur di Kota Batam; Untuk mengetahui apakah ajaran Islam difahami dari sisi aqidah dan ibadah saja, tetapi diharapkan dapat memberi kontribusi pemahaman ajaran Islam dari sisi mu'amallat yang merupakan bagian integral dari ajaran Islam yang kaffah; Untuk menganalisis pengaruh bekerja dan berproduksi terhadap prestasi kerja yang religius; Untuk menganalisis pengaruh kebutuhan sekunder terhadap prestasi kerja yang religius; Untuk menganalisis pengaruh kebutuhan primer terhadap prestasi kerja yang religius; Untuk menganalisis manakah pengaruh yang dominan antara bekerja dan berproduksi, kebutuhan sekunder, kebutuhan primer, terhadap prestasi kerja yang religius?

\section{Kerangka teoritik}

Dalam pandangan Maslow, semua manusia memiliki perjuangan atau kecenderungan yang dibawa sejak lahir untuk mengaktualisasikan diri. Manusia didorong oleh kebutuhankebutuhan yang universal yang dibawa sejak lahir, yang tersusun dalam suatu tingkat, dari yang paling lemah sampai yang paling kuat. Prasyarat untuk mencapai aktualisasi diri adalah memuaskan empat kebutuhan yang berada pada tingkat yang paling rendah, yaitu: kebutuhan fisiologis, kebutuhan rasa aman, kebutuhan memiliki cinta dan kebutuhan akan penghargaan.Aktualisasi diri dapat didefinisikan sebagai perkembangan dan penggunaan semua bakat yang paling tinggi, pemenuhan semua kualitas dan kapasitas karyawan. Orang yang mengaktualisasikan diri didorong oleh metamotivasi (metamotivation) (Ancok, 1994: 74). Sedang dalam teori yang diajukan Mursi (1997) aktualisasi diri identik dengan bekerja dan berproduksi dalam indikator variabel kebutuhan sekunder, hanya pendekatannya yang berbeda yaitu niat karena Allah dan dilakukan dalam konsep religius (Islam). Sesuai dengan klasifikasi motivasi teori Maslow yang dalam proses motivasi spiritual secara empiris sedang terjadi, maka rumusan masalah yang diajukan terdapat pengaruh klasifikasi motivasi menurut teori Maslow terhadap motivasi spiritual pada karyawan industri di Batam.

Menurut teori Maslow (1964) bahwa manusia didorong oleh kebutuhan-kebutuhan yang universal yang dibawa sejak lahir, tersusun dalam suatu tingkat, dari yang paling lemah sampai yang paling kuat, prasyarat untuk mencapai aktualisasi diri adalah memuaskan empat kebutuhan yang berada pada tingkat yang paling rendah, yaitu: kebutuhan fisiologis, kebutuhan rasa aman, kebutuhan memiliki cinta dan kebutuhan akan penghargaan. Aktualisasi diri dapat 
didefinisikan sebagai perkembangan yang paling tinggi dan penggunaan semua bakat perkembangan yang paling tinggi. Maka rumusan masalah yang diajukan adalah terdapat pengaruh motivasi kebutuhan sekunder terhadap prestasi kerja karyawan di Kota Batam.

Islam adalah agama yang bergerak dinamis, penuh energi dan tidak pernah mengenal kamus "berhenti dalam berbuat kebajikan, menggapai prestasi Illabiyab". Penghargaan Islam atas hasil karya dan upaya manusia untuk bekerja ditempatkan pada dimensi yang setara setelah iman, bahkan bekerja dapat menjadikan jaminan diampuni dosa-dosa manusia (Mursi, 1997: 23).

Membudayakan kebiasaan bekerja akan menjadi salah satu ciri utama setiap pribadi muslim yang menjadikannya sebagai the thought and spirit of time, citra dan semangat yang terus memberikan ilham dalam perjalanan kehidupannya, di mana akan terukir sejarah dengan tapak-tapak pribadi muslim yang prestatif. Demikian juga dalam berproduksi, seorang muslim harus memandang kehidupan ini sebagai arena yang memberikan tiga cakupan penting: tantangan, kekuatan, peluang dan perjuangan. Islam tidak mengenal kegemaran materialistis dari pola konsumsi modern (Mannan, 1995: 44).

Afzalur Rahman (1995) menguraikan bahwa perpindahan tenaga kerja dari suatu wilayah (geografis) ke wilayah lainnya, atau dari suatu jenis pekerjaan ke jenis yang lainnya disebut mobilitas tenaga kerja. Mobilitas ini terkait erat dengan kondisi ekonomi. Karena itu, pekerja dapat dengan mudah dan bebas pindah dari suatu tempat (atau pekerjaan) ke tempat (atau pekerjaan) lainnya dimana karyawan dapat memperoleh upah yang lebih baik sehingga dapat memperbaiki taraf hidupnya. Jika mobilitas tenaga kerja dibatasi, banyak tenaga kerja, terutama dari daerah-daerah terbelakang, tidak akan bisa mendapatkan upah yang layak. Orang yang bekerja di daerah yang kekurangan tenaga kerja akan dapat memperoleh bayaran yang lebih banyak dibanding jika bekerja di daerah-daerah yang tenaga kerjanya banyak tersedia.

Realisasi motivasi kebutuhan sekunder diperluas oleh Islam dengan mengakui hak-hak para pekerja dan menjamin kebebasan karyawan sepenuhnya untuk berpindah dari suatu tempat ke tempat lainnya (urbanisasi) atau dari suatu pekerjaan ke pekerjaan lainnya untuk mencari penghasilan yang lebih baik. Dalam al-Qur'an disebutkan, "Barang siapa berhijrah di jalan Allah (agar kondisi ekonominya lebih baik), niscaya karyawan mendapati di muka bumi ini tempat berhijrah yang luas dan rizqi yang banyak (QS. al-Nisa': 100). 
ljtihad, Jurnal Wacana Hukum Islam dan Kemanusiaan, Volume 13, No. 2, Desember 2013: 233-252

Kalangan konservatif dan karyawan yang tidak suka berusaha, karyawan yang lebih menyukai kehidupan miskin dan menolak meninggalkan rumah, ditegur oleh al-Qur'an dengan ungkapan sebagai berikut,'Dalam keadaan bagaimana kamu ini? Mereka menjawab, "Kami adalah orang-orang yang tertindas di negeri (Mekkah), (para Malaikat) berkata: 'Bukankah bumi Allah itu luas, sehingga kamu dapat berhijrah di bumi itu? (QS. Al-Nisa': 97). Berangkat dari ayat di atas, maka harus diakui bahwa pekerjaan merupakan hak, kewajiban dan kehidupan sesuai dengan potensi, kemampuan, pengetahuan dan pengalaman. Pribadi muslim yang qonaah harus mengeluarkan tenaga yang optimal dalam bekerja sehingga mampu merealisasikan kelayakan prestasi kerja. Sesungguhnya kelayakan prestasi kerja yang religius merupakan tujuan esensi bagi setiap masyarakat produktif, dengan berusaha merealisasikan tujuan tersebut.

Kelayakan prestasi kerja yang religius tercermin pada besarnya hasil produksi yang Islami, kualitas produk, efektivitas dan efisiensi, serta realisasi kepuasan karyawan pada tingkat maksimal yang diridhoi oleh Allah. Karena itu, sebaiknya karyawan diarahkan pada perkembangan kepribadian Islami yang produktif, yang memiliki ciri-ciri khusus, seperti kesesuaian kemampuan, keahlian, keterampilan dan pengalaman khusus pada tuntutan kesuksesan kerja; banyaknya ragam kecenderungan psikis kepribadian muslim untuk menjalankan suatu profesi; serta tingginya kadar kesesuaian kesehatan mental pada kepribadian muslim. Dalam hal prestasi kerja spiritual, ada beberapa ciri pokok diantaranya: bekerja secara profesional, memenuhi amanah bekerja, niat ikhlas, tawakal serta mendalami agama dan profesi. Nampaknya hal ini juga sangat dibutuhkan untuk memperbaiki prestasi kerja karyawan sehingga dapat mengurangi manipulasi sumber daya dan perilaku yang konsumtif atau pemborosan.

Rumusan masalah tersebut akan terjawab apabila digunakan pendekatan humanistik yang mengakui eksistensi agama. Diakui oleh Maslow sendiri dalam teorinya yang mengemukakan konsep metamotivation diluar kelima bierarchy of needs yang pernah dikemukakan. Mystical atau peak experience adalah bagian dari metamotivation yang menggambarkan pengalaman keagamaan. Pada kondisi ini manusia merasakan adanya pengalaman keagamaan yang sangat dalam. Pribadi (self) lepas dari realitas fisik dan menyatu dengan kekuatan transendental (self is lost and transcended). Di mata Maslow level ini adalah bagian dari kesempurnaan manusia (Ancok: 1994: 75). Ada kesempatan-kesempatan dimana orang-orang yang mengaktualisasikan diri 
mengalami ekstase, kebahagiaan, perasaan terpesona yang meluap-luap, suatu pengalaman keagamaan yang sangat mendalam. Selama pengalaman puncak ini, yang dianggap Maslow biasa terjadi di kalangan orang-orang yang sehat, diri dilampaui dan orang itu digenggam suatu perasaan kekuatan, kepercayaan dan kepastian, suatu perasaan yang mendalam bahwa tidak ada sesuatu yang tidak dapat diselesaikannya.

Maslow berpendapat bahwa ada dua klasifikasi motivasi, motivasi primer dan motivasi spiritual (seperti: keadilan, kebaikan, keindahan, kesatuan, dan ketertiban). Kebutuhan spiritual merupakan kebutuhan fitri yang pemenuhannya tergantung pada kesempurnaan kepribadian dan kematangan individu. Pada dasarnya manusia mempunyai potensi baik dan buruk. Kepribadian manusia terbuka ketika manusia mengalami kematangan potensial dalam bentuk yang lebih jelas. Bila manusia menjadi fanatis atau bengis, hal itu disebabkan oleh pengaruh lingkungan, selain faktor internal. Lingkungan berperan aktif membantu manusia mengaktualisasikan diri.

"Para pakar psikologi modern tidak memberikan perhatian pada studi-studi dimensi spiritual manusia dan kebutuhan-kebutuhan pokok tingkat tinggi. Padahal kebutuhan ini mempunyai kedudukan terpenting dan tertinggi yang melebihkan manusia dari seluruh ciptaan Tuhan yang lain. Komitmen para pakar psikologi modern terhadap penerapan metode ilmiah dalam studi manusia, mendorong mereka membatasi objek perhatiannya pada studi dimensi-dimensi tingkah laku manusia yang tunduk pada penelitian obyektif dan eksperimentasi. Sehingga mereka menjauhi penelitian dimensi tingkah laku manusia yang berhubungan dengan masalah spiritual. Mereka mengenyampingkan studi ini secara total" (Najati, 1982: 84).

Perbedaan motivasi antara Barat dengan Islam adalah bahwa Islam disamping memberikan insentif material dan keuangan, juga menggunakan insentif spiritual. Efektivitas insentif spiritual ini terbukti lebih kuat daripada yang material. Hal ini terjadi karena Islam selalu menyentuh hati setiap muslim dan mendorongnya untuk menjaga kesadaran Islamnya. Menurut Ancok (1994: 84) menyatakan bahwa variabel motivasi mu'amallat (spritual) telah diyakini oleh para ulama Islam dan orang yang belajar psikologi percaya lebih efektif dibandingkan dengan yang lain. Tetapi ini tidak berarti menghilangkan sama sekali motivasi material dan keuangan dalam diri manusia. 
ljtihad, Jurnal Wacana Hukum Islam dan Kemanusiaan, Volume 13, No. 2, Desember 2013: 233-252

Prinsip pokok prestasi kerja yang religius harus tercermin dalam sistem produksi yang Islami, karena produksi berarti diciptakannya manfaat, seperti juga konsumsi adalah pemusnahan produksi. Produksi tidak berarti menciptakan secara fisik sesuatu yang tidak ada, karena tidak seorangpun dapat menciptakan benda. Dalam pengertian ahli ekonomi, yang dapat dikerjakan manusia hanyalah membuat barang menjadi berguna disebut “dihasilkan". Prinsip fundamental yang harus selalu diperhatikan dalam proses produksi adalah prinsip kesejahteraan ekonomi. Bahkan dalam sistem kapitalis terdapat seruan untuk memproduksi barang dan jasa yang didasarkan pada asas kesejahteraan ekonomi. Keunikan konsep Islam mengenai kesejahteraan ekonomi terletak pada kenyataan bahwa kesejahteraan ekonomi itu tidak dapat mengabaikan pertimbangan kesejahteraan umum yang menyangkut persoalan moral, pendidikan, agama dan lain-lainnya. Dalam ekonomi modern kesejahteraan ekonomi diukur dari segi uang. Seperti kata Pigou: "Kesejahteraan ekonomi kira-kira dapat didefinisikan sebagai bagian kesejahteraan yang dapat dikaitkan dengan alat pengukur uang”. Kesejahteraan ekonomi modern bersifat materialistis, maka perlu membatasi ruang lingkup pokok persoalan yang sama (Mannan, 1995: 54).

Manusia sebagai khalifah Allah, telah diperintahkan untuk mengelola bumi guna kemakmuran dan kesejahteraan ekonomi. Allah swt. berfirman dalam Surat al-Sajdah ayat 4: "Allah-lah yang telah menciptakan langit dan bumi serta apa yang ada diantara keduanya dalam enam hari (masa)" (Depag RI, 1994: 660). Sebagai konsekuensi atas kesempurnaan manusia sebagai makhluk maka manusia dituntut untuk berprestasi kerja . Kelebihan yang telah diberikan Allah swt. kepada manusia adalah dalam rangka untuk mengabdi dan berprestasi kerja. Allah swt. berfirman dalam Surat Al-Isra' ayat 70:

"Dan sesungguhnya telah Kami muliakan anak-anak Adam dan Kami telah memberikan kepada mereka kendaraan di darat dan di laut dan Kami telah memberikan kepada mereka rezeki dari yang baik-baik dan Kami telah melebihkan mereka dari kebanyakan makhluk yang telah Kami ciptakan sebenar-benarnya lebih”(Depag RI, 1994: 435).

Prestasi kerja yang religius mengandung unsur tanggung jawab amanah, inovasi dan penelitian untuk pengembangan ilmu pengetahuan dan teknologi. Allah swt. berfirman dalam Surat al-Ahzab ayat 72: “Sesungguhnya Kami telah menawarkan suatu amanat kepada langit dan bumi dan gunung-gunung, maka mereka enggan memilikinya dan merasa tidak sanggup, 
tetapi diembannya oleh manusia" (Depag RI, 1994: 680). Kemampuan manusia memanfaatkan potensi alam adalah menunjukkan kemampuan prestasi kerja manusia atas delegasi kekuasaan Allah swt. yang telah dilimpahkan kepada manusia. Allah swt. berfirman dalam Surat Saba' ayat 12-13:

"Dan Kami tundukkan angin bagi Sulaiman, yang perjalanannya di waktu pagi sama dengan perjalanan sebulan dan perjalanannya diwaktu sore sama dengan perjalanan sebulan pula. Dan Kami alirkan cairan tembaga baginya dan sebagian dari jin ada yang bekerja dihadapannya (dibawah kekuasaannya) dengan izin Tuhannya. Para jin itu membuat apa yang dikehendaki Sulaiman dari gedung-gedung yang tinggi dan patung-patung dan piring-piring yang (besarnya) seperti kolam dan periuk yang tetap (berada di atas tungku)" (Depag RI, 1994: 685).

Manusia sangat dianjurkan untuk mengembangkan ilmu pengetahuan dan teknologi dalam rangka kemudahannya untuk mengabdi dan beribadah kepada Allah. Selanjutnya manusia diperintahkan untuk menembus ruang angkasa dengan kekuatan ilmu pengetahuan dan teknologinya (Sulthon), agar manusia mengagumi ciptaan Allah swt. dalam rangka proses prestasi kerja yang religius. Prestasi kerja yang religius selalu melibatkan ilmu pengetahuan dan proses produksi, sehingga kualitas prestasi kerja yang religius tidak sama dengan yang biasa.

\section{Metode penelitian}

Penelitian yang dilaksanakan untuk menguji pengaruh antar variabel yang berkaitan dengan motivasi spiritual dan kinerja yang religius, khususnya pada karyawan operasional, industri manufaktur yang ada di Kawasan Batamindo Kota Batam. Penelitian ini termasuk jenis penelitian survei dengan mengambil sampel dari populasi, yang menggunakan instrumen kuesioner sebagai alat untuk mengumpulkan data primer. Dengan demikian penelitian ini dianalisis dengan statistik inferensial yang dimaksudkan untuk menganalisis data sampel yang akan digeneralisasi kepada populasinya. Populasi pada penelitian ini adalah seluruh karyawan operasional dari perusahaan manufaktur yang ada di Kawasan Batamindo. Jumlah perusahaan manufaktur yang ada dalam Kawasan Batamindo Batam pada periode September- November 2001 mencapai 114 perusahaan, masing-masing perusahaan rata-rata mempekerjakan 1000 sampai dengan 2000 karyawan.Pengambilan sampel 10 perusahaan, diharapkan mampu 
ljtihad, Jurnal Wacana Hukum Islam dan Kemanusiaan, Volume 13, No. 2, Desember 2013: $233-252$

mewakili perusahaan manufaktur yang ada di Kawasan Batamindo. Untuk menentukan besar sampel yang berupa karyawan digunakan rumus (Parel, 1973 dalam Suparmoko, 1996: 40):

$$
\mathrm{n}=\frac{\mathrm{N} \cdot Z^{2} \cdot \mathrm{p} \cdot(1-\mathrm{p})}{\mathrm{N} \cdot \mathrm{d}^{2}+\mathrm{Z}^{2} \cdot \mathrm{p}(1-\mathrm{p})}
$$

dimana :

$\mathrm{n}=$ Besar sampel

$\mathrm{N}=$ Jumlah Populasi

$\mathrm{Z}=$ Luas area di bawah kurva normal

$\mathrm{p}=$ Proporsi

$\mathrm{d}=$ Derajat penyimpangan

Jumlah karyawan masing-masing perusahaan manufaktur yang telah ditentukan sebagai populasi sejumlah 1000 orang, dengan dugaan besarnya proporsi 0,5 dan penyimpangan tidak lebih dari 10\%, maka besarnya sampel dari masing masing perusahaan tersebut dapat dihitung sebagai berikut :

$$
\begin{aligned}
& \mathrm{n}=\frac{\mathrm{N} \cdot \mathrm{Z}^{2} \cdot \mathrm{p} \cdot(1-\mathrm{p})}{\mathrm{N} \cdot \mathrm{d}^{2}+\mathrm{Z}^{2} \cdot \mathrm{p}(1-\mathrm{p})} \\
& \mathrm{n}=\frac{1000 \cdot 1,960^{2} \cdot 0,5 \cdot(1-0,5)}{1000 \cdot 0,1^{2}+1,960^{2} \cdot 0,5(1-0,5)} \\
& \mathrm{n}=\frac{960,04}{15,9604}=60,260 \text { dibulatkan menjadi } 61 .
\end{aligned}
$$


Untuk menentukan siapa di antara para karyawan yang terpilih sebagai sampel, digunakan metode simple random sampling dengan mengikuti hukum probabilitas. Menurut hukum probabilitas, masing-masing warga populasi mempunyai peluang dan kemungkinan yang sama untuk terpilih sebagai sampel. Sampel merupakan elemen populasi yang dipilih untuk mewakili populasi dalam penelitian (Cooper dan Schindler, 2003:82). Model yang digunakan dalam penelitian ini adalah Structural Equation Modelling (SEM). Model pengukuran variabel motivasi mu'amallat (bekerja dan berproduksi, kebutuhan sekunder, kebutuhan promer, prestasi kerja yang religius) menggunakan Second Order Confirmatory Factor Analysis. Penaksiran pengaruh masing-masing variabel bebas terhadap variabel terikatnya menggunakan koefisien jalur

Tabel 1

Identitas Responden Menurut Jenis Kelamin

\begin{tabular}{ccc}
\hline Jenis Kelamin & Jumlah & Persentase \\
Laki-Laki & 98 & 15 \\
l'erempuan & 560 & 85 \\
Total & 658 & 100 \\
\hline
\end{tabular}

\section{Pembahasan dan temuan}

Berdasarkan hasil yang telah diperoleh, ternyata disimpulkan bahwa kebutuban sekunder dapat diukur berdasarkan indikator variabel yang tidak diobservasi (unobserved variable): kebutuhan primer (Kebprim), kebutuhan sekunder (Kebsek) dan kebutuhan bekerja serta berproduksi (Kerprod). Demikian juga masing-masing indikator Kebsek, dan Kebprim, dapat diukur melalui lima indikator variable observed yang sama, antara lain: keterlibatan ritual, keterlibatan ideologis (dogmatis), keterlibatan pengetahuan, keterlibatan pengalaman, serta keterlibatan konsekuensi. Hasil penelitian ini menunjukkan bahwa kebutuhan sekunder berpengaruh langsung positif terhadap prestasi kerja yang religius, yang ditunjukkan dengan koefisien jalur sebesar 1,38 dengan nilai probabilitas 0,00 (Tabel 2). Temuan ini memberi gambaran bahwa meningkatnya motivasi kebutuhan sekunder akan meningkatkan prestasi kerja religius apabila variabel lain konstan. 
ljtihad, Jurnal Wacana Hukum Islam dan Kemanusiaan, Volume 13, No. 2, Desember 2013: 233-252

Tabel 2

Pengaruh Mu'amallat terhadap Prestasi kerja yang Religius

\begin{tabular}{ccccc}
\hline Jalur & Koefisien Jalur & thitung & Probability (p) & Keterangan \\
Mu,amalat $\rightarrow$ Kinkel & 1,38 & 5,47 & 0.00 & Sionifikan \\
\hline
\end{tabular}

Adanya pengaruh positif motivasi kebutuban sekunder terhadap prestasi kerja yang religius sejalan dengan teori yang ditawarkan Mursi (1997) yang menyatakan bahwa dalam mu'amallat, seorang muslim akan memperhatikan tiga kebutuhan, yaitu primer, sekunder, dan bekerja dan berproduksi. Sesungguhnya kemiskinan akan mendekati kekufuran. Oleh karenanya, setiap pribadi muslim dituntut untuk bekerja agar dapat memenuhi kebutuhan tertentu yang diridhoi oleh Allah, sehingga harus diupayakan dengan penuh kesungguhan untuk mewujudkan prestasi yang optimal sebagai bukti pengabdian dirinya kepada Allah swt.

Menurut teori Max Weber (Swasono, 1988: 50) menyatakan bahwa ada hubungan langsung (fungsional) antara sistem nilai suatu agama dengan kegairahan bekerja para pemeluk ajaran agama, maka prestasi kerja karyawan juga dapat dipengaruhi oleh tingkat keikhlasan, kekhusukan dan kontinuitas ibadahnya. Teori Weber didukung oleh Zadjuli (1999: 10) yang menyatakan bahwa manusia sebagai khalifatullah dalam semua aktivitas hidupnya memiliki motif (niat) karena Allah, motivasinya didorong oleh ibadah untuk meningkatkan prestasi kerja yang religius (amal shaleh). Jika diperhatikan ajaran Islam melalui beberapa ayat alQur'an mengenai ibadah yang selalu terkait dengan outputproses produksi (mu'amallat) seperti zakat, perdagangan, amar ma'ruf nabi munkar dan prestasi kerja yang religius, tidak dapat diragukan bahwa karyawan yang ibadahnya kaffah (ikhlas, khusuk, kontinyu) akan mempunyai pengaruh positif signifikan terhadap prestasi kerja. Namun sebagaimana ditulis Amsyari (1995: 171) bahwa adanya pengaruh pemahaman aliran: "Aliran spiritualisasi agama membatasi Islam hanya untuk ritual dan itupun secara pelan-pelan diabaikan pelaksanaannya (salat pun makin jarang, berdoapun kalau sedang kesulitan, puasapun kalau tidak sakit maag dan semacamnya)."

Fenomena empiris menunjukkan karyawan industri di Batam mempunyai perilaku konsumtif, tetapi disertai dengan meningkatnya kegiatan keagamaan seperti ceramah agama, diskusi interaktif, bedah buku dan sebagainya yang menggambarkan motivasi spiritual sedang berproses. Apabila diamati secara cermat terdapat hirarki kebutuhan menurut teori Maslow, 
tetapi sedang berubah menuju motivasi spiritual, maka rumusan masalah yang diajukan apakah klasifikasi motivasi teori Maslow berpengaruh terhadap motivasi spiritual pada karyawan di Batam. Secara kuantitatif rumusan masalah ini dapat dijawab bahwa dari hasil pengujian melalui pengukuran koefisien jalur, ternyata motivasi kebutuhan sekunder yang paling dominan pengaruhnya terhadap prestasi kerja yang religius. Sedangkan dalam variabel kebutuhan sekunder indikator variabel yang diajukan adalah kebutuhan primer, kebutuhan sekunder. Kebutuhan primer adalah jenjang pemenuhan sandang, papan dan pangan, kebutuhan sekunder adalah pemenuhan kebutuhan kesehatan, pendidikan dan kesenangan, sedangkan bekerja dan berproduksi adalah setara dengan aktualisasi diri dalam teori Maslow sebagai hirarki (jenjang) tertinggi, hanya dalam konsep mua'amallat pendekatannya adalah religius sebagai bentuk pengabdian pada Allah (ibadah). Pengukuran kebutuhan sekunder (termodifikasi) dengan second order confirmatory factor analysis (Tabel 3.), menunjukkan loading factor yang dominan adalah kebutuhan sekunder $(1,00)$, tetapi jika dilihat pada hasil pengukuran pengaruh aqidah, ibadah, dan mu'amallat terhadap prestasi kerja dengan SEM didapat hasil bekerja dan berproduksi (Kerprod) yang paling dominan, dengan besaran loading factor 0,99 .

Tabel 3

Loading factor (l) Pengukuran Mu'amallat

\begin{tabular}{lcccc}
\hline Variabel indikator & I.oading factor $(\boldsymbol{\lambda})$ & $\mathbf{t}$ hitung & Probability $(\mathbf{p})$ & Keterangan \\
\hline KerProd & 0.97 & & & Signifikan \\
KebSek & 1.00 & 11.151 & 0.000 & Signifikan \\
KebPrim & 0.92 & 10.256 & 0.000 & Signifikan \\
\hline
\end{tabular}

Ketika kebutuhan sekunder diuji dalam model tersendiri maka kebutuhan sekunder (setara psikologi sosial, penghargaan dalam teori Maslow) menjadi dominan, tetapi ketika diuji bersama pengaruhnya dengan aqidah, ibadah dan mu'amallat (termodifikasi) maka hasil ujinya akan berbeda, yaitu bekerja dan berproduksi (setara aktualisasi diri dalam teori Maslow) menjadi dominan. Maslow menyampaikan teorinya bahwa ada klasifikasi motivasi primer (lima jenjang), dipandang masih ada jenjang tertinggi yaitu yang disebut dengan metamotivation atau motivasi spiritual (seperti: keadilan, kebaikan, keindahan, kesatuan dan ketertiban). Perbedaan cara pandang Maslow dengan Islam hanya pendekatan spiritualnya yang berbeda, 
ljtihad, Jurnal Wacana Hukum Islam dan Kemanusiaan, Volume 13, No. 2, Desember 2013: 233-252

Maslow tetap dalam koridor sekuler, sedangkan pengertian spiritual Islam adalah dalam rangka mengabdi kepada Allah (ibadah) secara totalitas sebagai konsekuensi khalifatullah.

Rumusan masalah yang diajukan, manakah di antara kebutuhan primer, kebutuhan sekunder, bekerja dan berproduksi yang paling dominan untuk menjadi variabel indikator dari faktor motivasi kebutuhan sekunder pada karyawan di Batam. Permasalahan ini berdasarkan fenomena empiris yang terjadi pada masyarakat industri modern, khususnya pada karyawan industri di Batam, yaitu terjadinya pola konsumsi yang cenderung konsumtif, dengan mengejar kebutuhan sekunder untuk kesenangan. Motivasi kebutuhan sekunder dalam kehidupan ekonomi adalah penting, karena kreativitas berarti meningkatnya kemakmuran masyarakat yang berarti meningkatnya konsumsi dan kesejahteraan sosial. Karena itu kebutuhan primer dan kebutuhan sekunder merupakan pasangan. Jika disejajarkan dengan teori kepuasan konsumsi maka dapat disejajarkan dengan kepuasan kreasi sebagai kepuasan primer yang fitri yang bersumber Rabman dan Rabim (Nataatmadja, 2001: 191). Berdasarkan teori tersebut, maka rumusan masalah yang diajukan kebutuhan sekunder merupakan variabel indikator yang paling dominan dari faktor motivasi kebutuhan sekunder pada karyawan di Batam.

Dari hasil loading factor kebutuhan sekunder dengan second order corfirmatory factor analisys pada Tabel 3 sebagai berikut:

1. Bekerja dan berproduksi loading factor $=0,97$ (signifikan)

2. Kebutuhan sekunder loading factor $=1,00$ (signifikan)

3. Kebutuhan primer loading factor $\quad=0,92$ (signifikan)

Angka tersebut menunjukkan bahwa antara kebutuhan sekunder, kebutuhan primer, bekerja dan berproduksi, kebutuhan sekunderlah yang variasinya paling besar dijelaskan oleh variasi dari motivasi kebutuhan sekunder. Dengan kata lain kebutuhan sekunder merupakan indikator yang paling kuat (dominan) dari motivasi kebutuhan sekunder.

Pola kebutuhan dalam motivasi kebutuhan sekunder bila dibandingkan dengan pola kebutuhan menurut Maslow yang berparadigma sekuler, terdapat pola yang sama secara fitrah manusia namun ada perbedaan pada cara pendekatan dan niatnya. Perbedaan antara ilmu ekonomi modern dengan ekonomi Islam dalam pola konsumsi terletak pada cara pendekatannya dalam memenuhi kebutuhan seseorang. Islam tidak mengakui kegemaran materialistis semata-mata dari pola konsumsi modern. Dominasi kebutuhan sekunder dalam 
motivasi kebutuhan sekunder sesuai firman Allah swt., "Hai anak Adam, pakailah pakaianmu yang di setiap (memasuki) masjid, makan dan minumlah, dan janganlah berlebih-lebihan. Sesungguhnya Allah tidak menyukai orang-orang yang berlebih-lebihan”.(QS. Al-A'raf: 31) Kecenderungan dominannya kebutuhan sekunder (psikologi religius), telah dibuktikan oleh Survei Pola Konsumsi Badan Pusat Statistik (1991-2012). Survei itu menunjukkan pengeluaran untuk memenuhi kebutuhan sekunder sebesar $62,56 \%$ sedangkan untuk kebutuhan primer sebesar $37,44 \%$.

Perintah untuk memenuhi kebutuhan sekunder maupun kebutuhan primer ada dalam al-Qur'an, tetapi semuanya itu dalam rangka meningkatkan prestasi kerja yang religius (amal shaleh) bukan untuk kepuasan semata-mata. Allah swt. berfirman, "Dan sesungguhnya pada binatang-binatang ternak, benar-benar terdapat pelajaran yang penting bagi kamu, Kami memberi minum kamu air susu yang ada dalam perutnya, dan (juga) pada binatang-binatang ternak itu terdapat faedah yang banyak untuk kamu dan sebagian dari kamu makan.” (QS. al-Mu'minun: 21) Pemenuhan kebutuhan sekunder dibenarkan oleh Islam akan tetapi ditujukan untuk meningkatkan prestasi kerja dan tidak boleh mengabaikan kebutuhan primer (pokok). Rasulullah menyimpulkan bahwa kebutuhan-kebutuhan pokok bagi setiap anggota masyarakat harus tersedia (Rahman, 1995: 0-1) Kebutuhan pokok seperti makanan, pakaian dan tempat tinggal, yang perlu bagi peningkatan efisiensi kerja disebut "kebutuhan tepat guna".

Memenuhi kebutuhan sekunder untuk meningkatkan prestasi kerja, dalam koridor keislaman dapat diartikan bahwa menikmati suatu kesenangan diperbolehkan dalam Islam. Islam sangat memahami naluri alamiah manusia dalam mengagumi dan menikmati keindahankeindahan dalam hidup ini. Islam juga mengakui kebutuhan-kebutuhan budaya manusia. Dalam masalah kebutuhan-kebutuhan manusia akan keindahan dan budaya secara alamiah, Islam membolehkannya mengikuti kebutuhan-kebutuhan pokok manusia, menikmati kesenangan-kesenangan. Pemenuhan kebutuhan sekunder dibenarkan oleh Islam. Al-Qur'an menganjurkan kepada kaum muslimin untuk menikmati hal-hal yang baik dan indah (QS. al-A'raf: 31). Jadi jelaslah bahwa pemuasan keinginan, termasuk kenyamanan-kenyamanan, keindahan dan perhiasan-perhiasan hidup dibolehkan dan dihalalkan asalkan untuk meningkatkan prestasi kerja, karena merupakan keinginan yang memberikan kesenangan 
ljtihad, Jurnal Wacana Hukum Islam dan Kemanusiaan, Volume 13, No. 2, Desember 2013: 233-252

dan kenyamanan kepada manusia dan yang memiliki manfaat (utility) yang lebih besar dari harganya.

Temuan ini menyimpulkan bahwa kebutuhan sekunder yang paling dominan sebagi variabel indikator, telah didukung oleh kenyataan empiris. Kecenderungan saat ini telah membuktikan bahwa semakin tinggi manusia menaiki jenjang peradaban, semakin terkalahkan ia oleh kebutuhan fisiologik karena faktor-faktor psikologis. Cita rasa seni, kebanggaan, dorongandorongan untuk prestise semua faktor ini memainkan peran yang semakin dominan dalam menentukan bentuk lahiriah konkret dari kebutuhan primer. Sebagai contoh pada peradaban masa lalu dalam suatu masyarakat primitif, konsumsi sangat sederhana, karena kebutuhannya juga sangat sederhana. Tetapi peradaban modern telah menghancurkan kesederhanaan manis akan kebutuhan-kebutuhan ini. Peradaban materialistik dunia Barat kelihatannya memperoleh kesenangan khusus dengan membuat semakin bermacam-macam dan banyaknya kebutuhankebutuhan karyawan. Kesejahteraan seseorang pun nyaris diukur berdasarkan bermacammacam sifat kebutuhan primer dan kebutuhan sekunder yang diusahakannya untuk dapat terpenuhi dengan upaya khusus. Pandangan terhadap kehidupan dan kemajuan ini sangat berbeda dengan konsepsi Islami.

Etika ilmu ekonomi Islam berusaha untuk mengurangi kebutuhan material manusia yang luar biasa sekarang ini, untuk menghasilkan energi manusia dalam mengejar cita-cita spiritualnya. Perkembangan batiniah yang bukan perluasan lahiriah, telah dijadikan cita-cita tertinggi manusia dalam hidup. Tetapi semangat masyarakat industri, sekalipun tidak merendahkan nilai kebutuhan akan kesempurnaan batin, namun rupanya telah mengalihkan tekanan ke arah perbaikan kondisi-kondisi kehidupan material. Kemajuan industri sering dipandang dengan semakin tingginya tingkatan hidup yang mengandung arti meluasnya kebutuhan primer dan kebutuhan sekunder, sehingga motivasi untuk mengejar tingkatan konsumsi yang semakin tinggi pun bertambah. Temuan pada penelitian ini telah membuktikan bahwa masyarakat Batam cenderung konsumtif apabila disertai dengan niat untuk kepuasan dunia saja. Tetapi loading factor sebesar 1,00 untuk kebutuhan sekunder pada motivasi kebutuhan sekunder menunjukkan gejala yang mendukung pada tingkat kedua setelah kebutuhan primer terpenuhi dan selanjutnya usaha tertinggi pada bekerja dan berproduksi setara dengan aktualisasi diri dapat ditunjukkan sesuai dengan teori motivasi oleh Abraham Maslow yang berpandangan, 
bahwa manusia memiliki perjuangan atau kecenderungan yang dibawa sejak lahir untuk mengaktualisasikan diri. Manusia didorong oleh kebutuhan-kebutuhan yang universal yang dibawa sejak lahir, yang tersusun dalam suatu tingkat, dari yang paling lemah sampai yang paling kuat prasyarat untuk mencapai aktualisasi diri adalah memuaskan empat kebutuhan yang berada pada tingkat yang paling rendah, yaitu: kebutuhan fisiologis, kebutuhan rasa aman, kebutuhan memiliki cinta dan kebutuhan akan penghargaan.

Ada tiga unsur yang menjadikan hidup manusia positif dan berguna. Pertama, mengimplementasikan potensi kerja yang dianugerahkan oleh Allah. Kedua, bertawakal kepada Allah, dan mencari pertolongan-Nya ketika melaksanakan pekerjaan. Ketiga, beriman kepada Allah swt. untuk menolak bahaya kediktatoran, kesombongan atas prestasi yang dicapai. Allah swt. berfirman, dalam: "Dan carilah pada apa yang telah dianugerahkan Allah kepadamu (kebahagiaan) negeri akhirat, dan janganlah kamu melupakan bagian-mu dari (kenikmatan) duniawi” (QS. al-Qashash: 77). Bukti bahwa bekerja dan berproduksi yang seharusnya dominan dapat dicermati pada perintah Allah swt., "Apabila telah ditunaikan sembahyang maka bertebaranlah kamu di muka bumi dan carilah karunia Allah dan ingatlah Allah banyak-banyak supaya kamu beruntung" (QS. al-Jumu'ah: 10). Ayat-ayat tersebut di atas menjelaskan tentang manusia sebagai makhluk yang direncanakan Allah swt. untuk bekerja dan berproduksi. Dalam beberapa ayat al-Qur'an tersebut dapat disimpulkan tentang potensi manusia untuk bekerja dan berproduksi secara religius untuk memenuhi tugas kekhalifahan manusia dalam kerangka kebutuhan sekunder menuju tercapainya "rahmatan lil 'alamin".

Dalam penelitian yang dilakukan oleh Hagemann (1993: 30-32) menunjukkan kesamaan dengan dominasi kebutuhan sekunder pada motivasi kebutuhan sekunder, sebagaimana faktor-faktor yang memotivasi karyawan sebagai berikut: Lebih 60\% memberikan jawaban yang berhubungan dengan pemenuhan kebutuhan sosio-psikologis: umpan balik, rasa memiliki, keterbukaan, kejujuran, kredibilitas, kepercayaan, keadilan, perhatian, tanggung jawab, partisipasi; Sekitar 20\% jawaban berhubungan dengan pemenuhan kebutuhan intelektual: rasa pemenuhan diri, tugas yang menarik dan bervariasi tantangan; Hanya 10\% yang menyinggung rangsangan materi; Hanya $10 \%$ yang menganggap kualitas ruangan sangat penting (Hagemann, 1993: 30-31). 
Rumusan masalah yang diajukan, manakah yang memiliki pengaruh dominan terhadap prestasi kerja yang religius diantara motivasi akidah, motivasi ibadah dan mu'ammalat pada karyawan di Batam. Dominannya motivasi kebutuhan sekunder dibandingkan dengan motivasi aqidah maupun motivasi ibadah, karena kehidupan material masih menjadi tujuan dan dorongan karyawan maupun masyarakat industri pada umumnya. Indikator variabel yang diajukan untuk kebutuhan sekunder diantaranya mengatur kebutuhan primer (kebutuhan pokok), kebutuhan sekunder (kesenangan) dengan syarat untuk meningkatkan prestasi kerja, sedangkan kebutuhan tersier (kemewahan) dilarang dalam Islam karena dipandang tidak untuk meningkatkan prestasi kerja tetapi dipandang sebagai pemborosan dan pemusnahan sumber daya. Bekerja dan berproduksi adalah bagian dari kebutuhan sekunder yang dapat dikategorikan sebagai prestasi prestasi kerja seorang muslim menuju tercapainya rahmatan lil 'alamin.

Motivasi kebutuhan sekunder adalah dorongan kekuatan dari dalam untuk memenuhi kebutuhan manusia yang dilandasi oleh kekuatan moral spiritual, sehingga dapat menghasilkan prestasi kerja yang religius, karena diilhami oleh al-Qur'an dan al-Sunnah. Kebutuhan dan urutan prioritas biasanya dalam tiga tingkatan: keperluan, kesenangan, dan kemewahan.

1. Kebutuhan primer biasanya meliputi Kebutuhan primer biasanya meliputi semua hal yang diperlukan untuk memenuhi segala kebutuhan dasar yang harus dipenuhi.

2. Kebutuhan sekunder boleh didefinisikan sebagai komoditi yang penggunaannya menambah efisiensi karyawan, akan tetapi tidak seimbang dengan biaya komoditi yang dibayarkan (dikeluarkan).

3. Kemewahan menunjuk kepada komoditi serta jasa yang penggunaannya tidak menambah efisiensi seseorang bahkan mungkin menguranginya, seperti baju, perhiasan, mobil, dan mebel mahal, kesemuanya itu merupakan kemewahan bagi kebanyakan orang.(Mannan, 1995: 48)

Dari teori yang diajukan oleh Mannan, maka rumusan masalah yang diajukan adalah motivasi kebutuhan sekunder memiliki pengaruh yang paling dominan terhadap prestasi kerja yang religius pada karyawan di Batam. Dengan demikian motivasi mu'amalat adalah yang paling dominan pengaruhnya terhadap prestasi kerja yang religius yang ditandai dengan angka koefisien jalur sebesar 1,38. Koefisien jalur ini terbesar bila dibanding koefisien jalur lainnya. Dari hasil berarti rumusan masalah terjawab, serta rumusan masalah yang diajukan 
didukung oleh fakta atau dapat diterima. Dalam motivasi kebutuhan sekunder mempunyai ciri-ciri tertentu; diantaranya yang mencolok, tidak ada perbedaan antara kebutuhan spiritual dengan kebutuhan keduniawian. Pada agama-agama lain yang ada di dunia ini terdapat pemisahan antara keperluan keagamaan dan bukan keagamaan atau keperluan keduniawian.

Motivasi kebutuhan sekunder memang berpengaruh dominan terhadap prestasi kerja yang religius, bukan berarti motivasi ini harus dikurangi, tetapi yang penting adalah motivasi ibadah yang seharusnya positif sehingga motivasi aqidah dan motivasi kebutuhan sekunder dapat sama mempunyai koefisien jalur yang positif dan seimbang (equilibrium), sesuai dengan do'a yang memohon kepada Allah swt. agar diberi kebahagiaan hidup didunia (alam material) dan kebahagiaan hidup di akherat (alam spiritual), agar manusia selalu berorentasi pada kesimbangan sesuai dengan perintah Allah, "Dan carilah pada apa yang telah dianugerahkan Allah kepadamu (kebahagiaan) negeri akhirat, dan janganlah kamu melupakan bagian-mu dari (kenikmatan) duniawi” (QS. Al-Qashash: 77).

\section{Penutup}

Dengan diterapkannya motivasi mu'amallat untuk meningkatkan prestasi kerja yang religius, akan mengurangi perilaku yang konsumtif, materialistik dan sikap fatalisme, karena semua dilakukan dengan niat ikhlas karena Allah. Adanya hubungan langsung (fungsional) antara sistem nilai suatu agama dengan kegairahan bekerja para pemeluk ajaran agama sebagaimana dikatakan Max Weber. Ibadah adalah salah satu bentuk pengabdian (peribadatan) yang dilandasi oleh tauhid, tidak akan ada ibadah tanpa tauhid.

Manusia terkuras energinya oleh karena mengejar kepuasan fisiologis oleh faktor psikologis (kebutuhan sekunder). Islam memandang bahwa kesenangan (kebutuhan sekunder) dibolehkan asalkan dapat untuk meningkatkan kinerja yang religius. Kebutuhan sekunder (1,00 positif signifikan) adalah variabel indikator yang dominan bila dibandingkan dengan kebutuhan primer $(0,92)$, bekerja dan berproduksi $(0,97)$. Jika mu'amallat diuji bersama aqidah dan ibadah maka yang dominan adalah bekerja dan berproduksi, bukan kebutuhan sekunder, hasil uji ini menunjukkan bahwa aqidah dan ibadah akan mampu merubah perilaku mu'amalatnya.

Dominannya motivasi kebutuhan sekunder dibandingkan dengan motivasi bekerja dan berproduksi dan motivasi kebutuhan primer, menunjukkan kehidupan material-prestise 
ljtihad, Jurnal Wacana Hukum Islam dan Kemanusiaan, Volume 13, No. 2, Desember 2013: 233-252

(kesenangan) masih menjadi tujuan dan dorongan utama karyawan maupun masyarakat industri pada umumnya. Indikator variabel yang diajukan untuk mu'amallat diantaranya mengatur kebutuhan primer (kebutuhan pokok), kebutuhan sekunder (kesenangan) dengan syarat untuk meningkatkan kinerja ternyata mempunyai pengaruh yang paling dominan, sedangkan kebutuhan tersier (kemewahan) dilarang dalam Islam karena dipandang tidak untuk meningkatkan kinerja tetapi dipandang sebagai pemborosan dan pemusnahan sumber daya. Bekerja dan berproduksi yang didorong oleh motivasi kebutuhan sekunder namun dituntun oleh ajaran Islam, dapat dikategorikan sebagai prestasi kerja seorang muslim menuju tercapainya rahmatan lil 'alamin.

\section{Daftar pustaka}

Amsyari, Fuad. Islam Kaffah Tantangan Sosial dan Aplikasinya di Indonesia. Jakarta: Gema Insani Press, 1995.

Ancok, Djamaludin. Psikologi Islam. Yogyakarta: Pustaka Pelajar, 1994.

BPS Kota Batam. Laporan Tahunan Perekonomian Batam. Batam: BPS-Otorita Batam, 2000. Cooper, R. Donald., \& Pamela, S. Schindler. Business Research Methods. Eight Edition. New York: Mc. Graw-Hill/Irwin, 2003.

Departemen Agama RI. Al-Qur'an dan Terjemahannya. Jakarta: Bumi Restu, 1990..

Hagemann, Gisela. Motivasi untuk Pembinaan Organisasi, terjemahan. Jakarta: Gramedia, 1993. Maslow AH., "A Theory of Motivation”, dalam Psychological Review No. 50, 1943.

Maslow AH. Religions, Values and Peak Experiences. Columbus Ohio: Ohio University Press, 1964.

Manan, M. Abdul. Teori dan Praktek Ekonnomi Islam. Yogyakarta: Dana Bhakti Wakaf, 1995. Mursi, Abdul Hamid. Sumber Daya Manusia yang Produktif. Jakarta: Gema Insani Pers, 1997. Najati, Muhammad Utsman. Al-Qur'an wa 'Ilman Nafs. Kairo: Darus Syuruq, 1982.

Najati, Muhammad Utsman. Jiwa Manusia dalam Sorotan Al-Qur'an. Jakarta: Cendekia, 2001.

Nataatmadja, Hidayat. Intelegensi Spiritual. Jakarta: Perenial Press, 2001.

Rahman, Afzalur. Doktrin Ekonomi Islam 1 \& 2. Jakarta: Dana Bhakti Wakaf, 1995.

Suparmoko. Metode Penelitian Praktis. Yogyakarta: BPFE, 1996.

Swasono, Sri Edi. Sekitar Kemiskinan dan Keadilan. Jakarta: UI Press, 1988.

Zadjuli, Suroso Imam. Kajian Karakteristik Kegiatan Sosial, Ekonomi, Kependudukan dan Lingkungan Di Kota Batam. Surabaya: Suroso Imam Zadjuli \& Associates Consultant, 2001. 